\title{
CORROSION RESISTANCE OF ZINC COATINGS WITH ALUMINIUM ADDITIVE
}

\author{
Jiří VOTAVA \\ Mendel University in Brno, Czech Republic
}

This paper is focused on evaluation of anticorrosion protection of inorganic metal coatings such as hot-dipped zinc and zincgalvanized coatings. The thickness and weight of coatings were tested. Further, the evaluation of ductile characteristics in compliance with the norm ČSN EN ISO 20482 was processed. Based on the scratch tests, there was evaluated undercorrosion in the area of artificially made cut. Corrosion resistance was evaluated in compliance with the norm ČSN EN ISO 9227 (salt-spray test). Based on the results of the anticorrosion test, there can be stated corrosion resistance of each individual protective coating. Tests were processed under laboratory conditions and may vary from tests processed under conditions of normal atmosphere.

Keywords: corrosion, zinc coating, steel

The current trend not only in the automotive industry is the usage of zinc coating as an anticorrosion protection of steel parts. Inorganic coatings and duplex protection is used for body shells of vehicles and, e.g. for protection of exhaust piping (Pejčoch, 2006). At different regimes and different service temperature, the exhaust piping is subject to an increased corrosion pressure. This aspect also indicates the variety of harmful emissions in exhaust gases (Kotus et al., 2012; Veverka et al., 2011). Corrosion aggressiveness also depends on the chemical composition of fuel used. Due to reducing the usage of fossil fuels, there are nowadays performed analyses of using biogas in gas engines (Žarnovský, 2012).

If the vehicle body shell is protected by a $\mathrm{Zn}-\mathrm{Al}$ coating, it is possible to join the individual parts by welding. The technology of cold metal transfer currently guarantees a reliable creation method of weld bead of such protected steel parts. The joint could not be done using common technologies such as hard-facing or welding. Not only the anticorrosion protection would be harmed but also the welding bath would be affected by $\mathrm{Zn}-\mathrm{Al}$ elements, which is undesirable (Čičo et al., 2006).

The advantage of inorganic coatings is the possibility of combination of more elements in the protective coating (Trethewey, 1995).

\section{Material and methods}

The goal of the experiment is to compare the anticorrosion characteristics of zinc hot-dipped and zinc-galvanized coating. The criterion is the content of aluminium in the anticorrosion coating. The individual analyses were performed on samples with a defined coating thickness and chemical composition. One of the analyses is monitoring the self-healing effect of the damaged coating.

\section{Characteristics of tested coatings}

The zinc dipping of a steel sheet with a thickness of more than $1 \mathrm{~mm}$ is an anticorrosion protection formed by inorganic metal coating. The process of zinc dipping consists of the following steps: degreasing, chemical cleaning, flush, flux application, drying, dipping in melted zinc, and cooling. One of the main factors influencing the thickness of the coating is the time of dipping in zinc bath (Ščerbejová, 1993; Dillinger, 2007). There were prepared 30 samples under operating conditions of zinc works.

The zinc dipping of a steel sheet up to $1 \mathrm{~mm}$ of thickness: thin sheet is zinc-dipped in continual facilities where the whole process is connected to a closed system. First of all, the coiled sheet is degreased and cleansed from oxides. Further, the sample is zinc-dipped in zinc bath. Regularity of the zinc coating is ensured by an air scraper knife. The steel sheet is either zinc-dipped by micro-alloyed, low-alloyed or high-alloyed zinc. The most common alloying element is aluminium. For the experiment, there was prepared a set of samples with the aluminium content up to $5 \%$ (Galfan) and up to $55 \%$ (Galvalume). Samples were delivered by their manufacturer.

Galvanizing: the steel surface of the machine part has to be degreased first of all. The object is hung into an aqueous solution of zinc salt (electrolyte), which is afterwards connected to electric current and figures as a cathode (Svoboda, 1985). Pure zinc (99.995 \% Zn) plates play the role of an anode. There were prepared 30 samples under operating conditions of zinc works.

The chemical composition of individual zinc coatings can be found in Table 1.

To evaluate the individual coatings, the following analyses were performed:

- measurement of coating weight and thickness according to ČSN EN ISO 3892;

- ductile characteristics - Erichsen's test (ČSN EN ISO 20482);

- evaluation of corrosion degree in the area surrounding the cut;

- evaluation of corrosion resistance in the salt-spray environment ČSN ISO EN 9227.

\section{Thickness of anticorrosion coating}

One of the decisive factors influencing the durability of anticorrosion coatings is their thickness (Votava et al., 2011). 
Table 1 Chemical composition of tested anticorrosion coatings

\begin{tabular}{|l||c|c|c|c|c|}
\hline Spectrum & Al in $\%_{p w}$ & Si in $\%_{p w}$ & Cl in $\%_{p w}$ & Fe in $\%_{p w}$ & Zn in ${ }_{p w}$ \\
\hline \hline Hot-dipped zinc & 1.10 & 0.78 & 0.15 & 5.60 & 90.07 \\
\hline Zinc with 5 \% Al & 4.80 & 6.10 & 1.50 & 2.15 & 83.16 \\
\hline Zinc with 55 \% Al & 52.00 & 1.30 & 0.36 & 2.64 & 42.10 \\
\hline Galvanized zinc & 0.29 & 0.16 & 0.21 & 3.22 & 94.27 \\
\hline
\end{tabular}

Table 2 Thickness of anticorrosion coatings

\begin{tabular}{|c|c|c|c|c|c|c|c|}
\hline & \multicolumn{4}{|c|}{ Measurement of thickness in $\mu \mathrm{m}$} & \multirow[t]{2}{*}{ Average } & \multirow{2}{*}{$\begin{array}{l}\text { Standard } \\
\text { deviation }\end{array}$} & \multirow{2}{*}{$\begin{array}{c}\text { Variation } \\
\text { coefficient in \% }\end{array}$} \\
\hline & no. 1 & no. 2 & no. 3 & no. 4 & & & \\
\hline Hot-dipped zinc & 65.30 & 76.00 & 51.30 & 59.10 & 62.93 & 9.03 & 14 \\
\hline Zinc with $5 \%$ Al & 18.30 & 15.90 & 17.30 & 18.60 & 17.53 & 1.05 & 6 \\
\hline Zinc with $55 \%$ Al & 33.50 & 31.90 & 32.50 & 31.10 & 32.25 & 0.88 & 3 \\
\hline Galvanized zinc & 8.90 & 10.90 & 9.30 & 11.60 & 10.18 & 1.11 & 11 \\
\hline
\end{tabular}

The Association of Czech and Slovakian Zinc Works (Asociace českých a slovenských zinkoven) states in its researches that depending on the environment the coating decrease is from $0.64-1.57 \mu \mathrm{m}$ per year. These data are recorded into so called corrosion maps.

In order to determine the coating thickness, either a destructive or a non-destructive method can be used. The destructive method consists of preparation of metallographic samples and measuring the coating thickness at a particular magnification of a metallographic microscope. The non-destructive method can either use ultrasonic waves or rotational flows.

In this experiment, coating thickness was measured using a non-destructive method - measuring probe for ferromagnetic basis. Measured values are recorded in Table 2.

\section{Weight measurement by a gravimetric method in compliance with ČSN EN ISO 3892}

The ČSN EN ISO 3892 norm establishes the exact process while finding out the weight of the protective layer applied onto a surface. It lies in a gradual decontamination of the metal coating out of the surface of the base material. The final reading is given as the average value out of three measurements. Weight was measured using laboratory scale with precision to $1 \mathrm{mg}$. Before the test, the samples

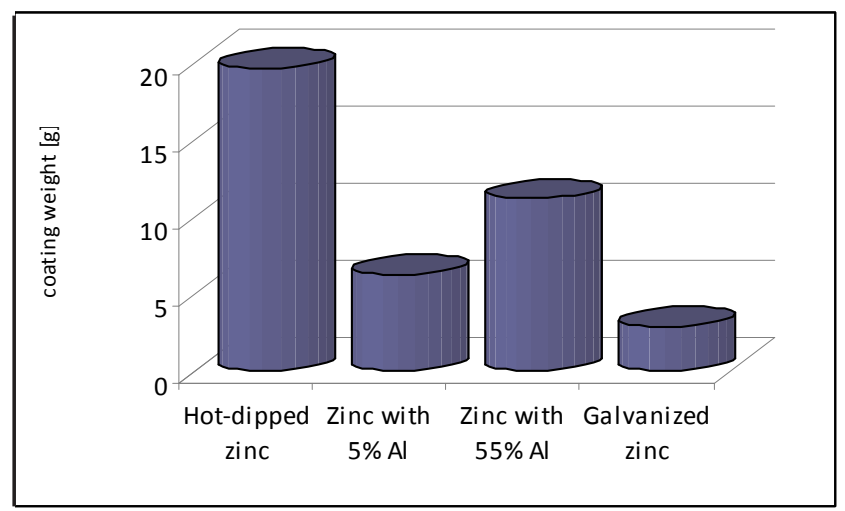

Figure 1 Weight of anticorrosion coatings were cleansed and weighed. Further, the samples were subject to the gradual decontamination of the passivation layer. The decontamination interval was established as 5 minutes under laboratory temperature. After the interval had passed, the samples were cleansed with running water and weighed again. The whole process was repeated until a constant decrease was reached. The results of the weight decrease are shown in Figure 1.

The solution used to decontaminate the passivation layer was aqueous solution containing in one litre of distilled water $200 \mathrm{~g}$ of $\mathrm{CrO}_{3}$ and $10 \mathrm{~g}$ of $\mathrm{BaCO}_{3}$.

\section{Erichsen cupping test}

The international norm ČSN EN ISO 20482 specifies a standard testing method of finding out the ability of metal sheets and strips (with the thickness from $0.1 \mathrm{~mm}$ to $2 \mathrm{~mm}$ and wideness of $90 \mathrm{~mm}$ and more) to deform themselves when mechanical working by cupping.

A punch with a ball-shaped ending is pressed into a sample which is fixed between a holder and the punch and causes cupping until a crack originates. Measured depth is the outcome of this test which is based on the punch movement. Penetration depth is measured with the accuracy of $0.1 \mathrm{~mm}$.

Results of the cupping test show a correlation of mechanical characteristics and technology of anticorrosion coating application (see Table 3). The hot-dipped zinc coating is about three times less resistant to mechanical stresses than the galvanized coating. It is apparent that hard intermetallic phases originating in the process of zinc dipping are not able to resist mechanical stresses (bending, twisting).

\section{Evaluation of corrosion degradation in the area surrounding the cut}

If any anticorrosion coating looses its compactness, the corrosion resistance of the whole system decreases. The subject-matter of anticorrosion protection is to eliminate the access of air humidity to the base steel material. If the anticorrosion protection is formed by a less noble metal than the base material, oxidation processes run firstly in 
Table 3

Test according to Erichsen

\begin{tabular}{|c|c|c|c|c|c|c|c|}
\hline & \multicolumn{4}{|c|}{ Measurement of depth in $\mathbf{m m}$} & \multirow[t]{2}{*}{ Average } & \multirow{2}{*}{$\begin{array}{l}\text { Standard } \\
\text { deviation }\end{array}$} & \multirow{2}{*}{$\begin{array}{c}\text { Variation } \\
\text { coefficient in \% }\end{array}$} \\
\hline & no. 1 & no. 2 & no. 3 & no. 4 & & & \\
\hline Hot-dipped zinc & 2.30 & 2.10 & 1.90 & 2.20 & 2.13 & 0.15 & 7 \\
\hline Zinc with $5 \%$ Al & 4.70 & 4.50 & 4.50 & 4.30 & 4.50 & 0.14 & 3 \\
\hline Zinc with $55 \%$ Al & 3.20 & 3.30 & 2.90 & 3.30 & 3.18 & 0.16 & 5 \\
\hline Galvanized zinc & 6.10 & 5.90 & 6.30 & 6.40 & 6.18 & 0.19 & 3 \\
\hline
\end{tabular}
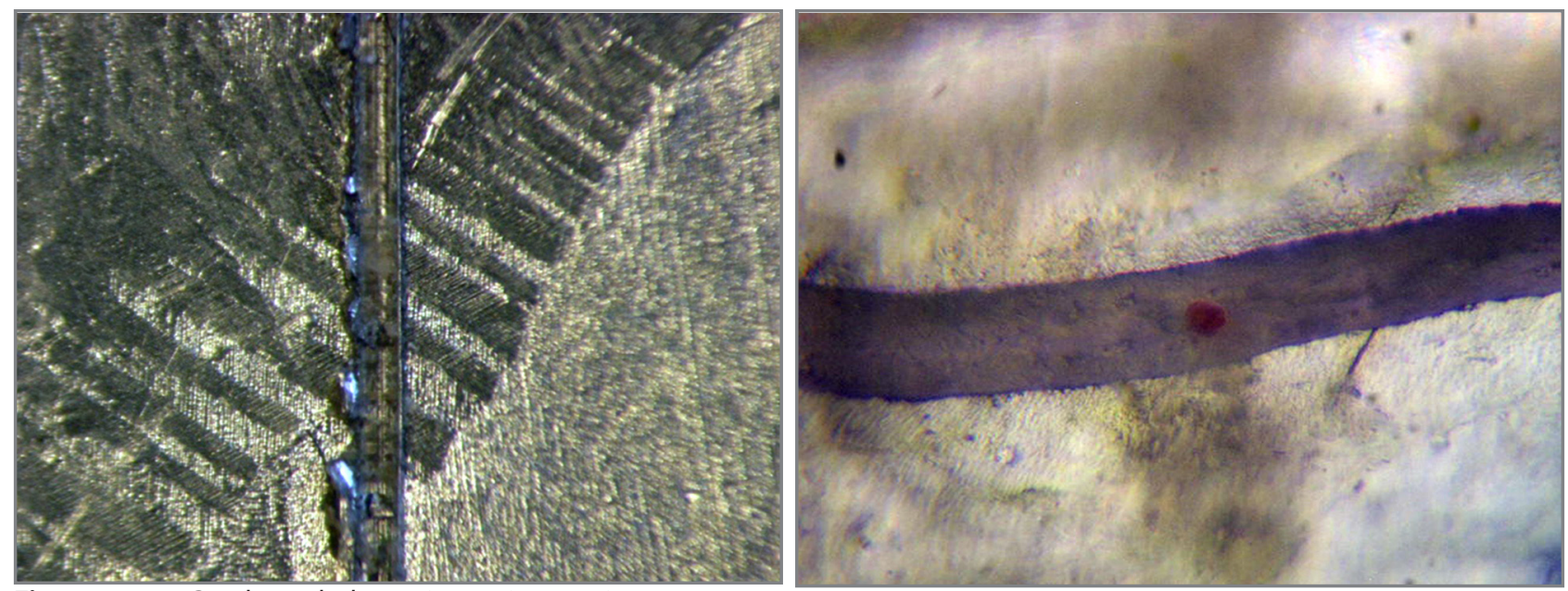

Figure 2 Cut through the anticorrosion coating

this coating. In case of failure of the integrity of the anticorrosion coating, passivation of the base material (steel) should be guaranteed. The evaluation of corrosion attack in the area surrounding a cut or a different artificially created defect is defined in the norm ČSN EN ISO 4628-8. This norm is applicable to paint systems only.

As apparent from Figure 2, red corrosion of the base material in the cut area appears the first day of salt-spray environment exposition. However, depending on corrosion speed, the entire sample surface is covered by zinc hydroxide, which forms a further anticorrosion barrier which could be called 'self-healing effect'. For this reason, it is impossible to evaluate the undercorrosion of the anticorrosion coating around the defect.

\section{Evaluation of corrosion resistance of coatings used}

The corrosion resistance of individual protective systems was tested according to the norm ČSN ISO 9227 - Salt spray test (NSS method). There were prepared 10 test samples from each anticorrosion coating. The samples were afterwards put into a special stand and were exposed to an aggressive salt-spray environment. Corrosion attack was evaluated using a visual method.

Test parameters:

- temperature in the salt-spray chamber $35 \pm 2{ }^{\circ} \mathrm{C}$;

- concentration of sodium chloride in a spraying medium $50 \pm 5 \mathrm{~g} \mathrm{l}^{-1}$;

- $\mathrm{pH}$ value of the salt solution 6.5-7.2;
- the time interval was set for 2, 7, 10, 20 and 40 days. Based on an every-day visual evaluation and depending on the speed of corrosion degradation, the individual intervals may differ.

As Figure 3 shows, the corrosion degradation of anticorrosion coating in the salt-spray environment depends on the chemical composition of the

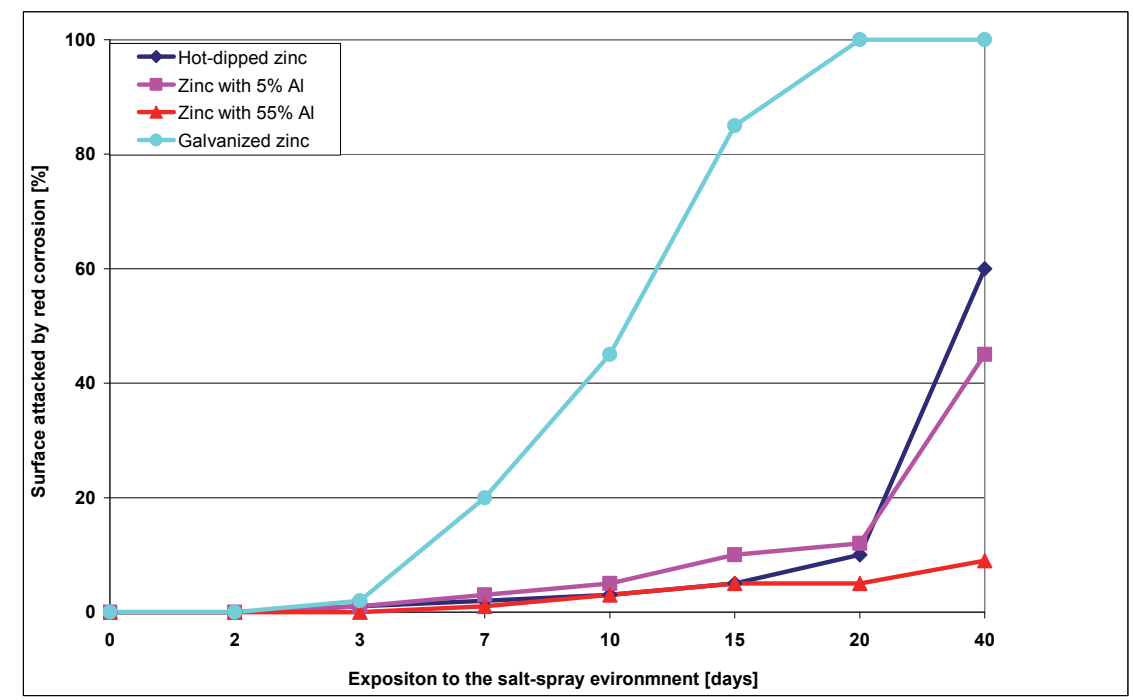

Figure 3 Corrosion development in individual samples 


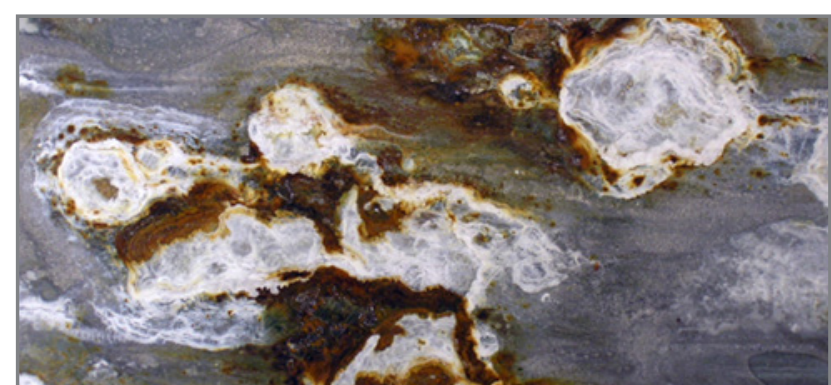

Figure 4 Corrosion attack of galvanized zinc

protective coating. Adding aluminium to the protective coating prolongs its life significantly. The galvanized coating has showed red corrosion after a 3-day salt-spray exposition, see Figure 4.

The pace of corrosion degradation is affected by ambient temperature, too. At temperature exceeding $100{ }^{\circ} \mathrm{C}$, intermetallic phases convert. The current trend in the automotive industry is identifying the influence of raising temperature on functional engine parts by a thermal imaging camera (Žarnovský, 2012).

\section{Conclusions}

The current trend in anticorrosion protection is creation of such anticorrosion coatings which protect the metal part using the principle of different electrolyte potential of both metals. Protective coating is formed by a metal with a lower electrolyte potential than steel. This aspect results in an initial oxidation of protective coating and a further passivation of metal part. Also duplex systems have a big advantage.

One of the most commonly used inorganic anticorrosion coatings are zinc coatings. In order to increase the anticorrosion resistance, these anticorrosion coatings are alloyed (mostly by aluminium) if the technology enables it.

The experiment has showed a direct influence of aluminium on increasing anticorrosion protection. Samples with up to $5 \%$ of aluminium have similar characteristics to hot-dipped samples. Samples with up to $55 \%$ of aluminium have an excellent anticorrosion resistance in the salt-spray environment - after a 40-day exposition, surface attack by red corrosion was just $10 \%$.

The combination of individual elements for anticorrosion protections is one of the possibilities to increase the reliability of passivation coatings.

\section{References}

ČIČO, P. - TOLNAI, R. - KOTUS, M. 2006. Kvalita návaru pri impulznom a bezimpulznom naváraní synergickým zváracím zdrojom. In Acta Technologica Agriculturae, vol. 9, 2006. no. 1, pp. 3-6.

ČSN EN ISO 20482: 2004. Zkouška hloubením podle Erichsena: Kovové materiály - plechy a pásy.

ČSN EN ISO 3892: 2002. Konverzní povlaky na kovových materiálech. Stanovení plošné hmotnosti povlaku - Vážková metoda.

ČSN ISO 9227: 1994. Korozní zkoušky v umělých atmosférách. Zkouška solnou mlhou.

DILLINGER, J. 2007. Moderní strojírenství pro školu i praxi. Praha : Europa sobotáles, 2007. 612 pp. ISBN 978-80-86706-19-1.

KOTUS, M. - ANDRÁSSYOVÁ, Z. - VEVERKA, J. - KROČKO, V. - FRIES, J. 2012. Porovnanie obsahu škodlivých emisií vybraných motorov značiek Škoda a Seat. In Technická diagnostika strojů a výrobních zařízení "DIAGO 2012". Ostrava : VŠB - Technical University of Ostrava, 2012. pp. 103-107.

PEJČOCH, M. - CHRÁST, V. - ČERNÝ, M. 2006. Aspekty protikorozní ochrany automobile. In Kvalita a spol'ahlivost' technických systémov. Nitra : SUA in Nitra, 2006. pp. 157-160. ISBN 80-8069-707-8.

ŠČERBEJOVÁ, M. 1993. Strojírenská technologie. Brno :Vysoká škola zemědělská v Brně, 1993. 132 pp. ISBN 80-7157-083-4.

SVOBODA, M. 1985. Protikorozní ochrana kovů galvanickými povlaky. Praha: SNTL, 1985. 235 pp. ISBN 04-603-85.

TRETHEWEY, K.R. - CHAMBERLAIN, J. 1995. Corrosion: for science and engineering. Addison : Wesley Longman, 1995. 466 pp. ISBN 0-582-238692.

VEVERKA, J. - KOTUS, M. - ANDRÁSSYOVÁ, Z. - HUJO, L. 2011. Vplyv teploty motora na zloženie výfukových plynov. In Najnovšie trendy $\checkmark$ pol'nohospodárstve, $v$ strojárstve a v odpadovom hospodárstve. Nitra : SUA in Nitra, 2011. pp. 222-227. ISBN 978-80-552-0588-5.

VOTAVA, J. - BEDNÁR̆, R. - FAJMAN, M. - CHRÁST, V. 2011. Combined systems of anticorrosion protection. In Deterioration, Dependability, Diagnostics. Brno: University of Defence Brno, 2011. pp. 249-256. ISBN 978-80-260-0633-6.

ŽARNOVSKÝ, J. - BERNÁT, R. - KOVÁČ, I. - KOTUS, M. 2009. Sledovanie pracovného priestoru motora pri používaní bioplynu. In Nové trendy v prevádzke technických systémov '09. Prešov : Technical University in Košice, 2009. pp. 104-106. ISBN 978-80-553-0311-6.

ŽARNOVSKÝ, J. - KOTUS, M. - ŽITŇANSKÝ, J. - DRLIČKA, R. RUTTKAY, L. 2012. Využiti termovízie v diagnostike vozidiel. In Technická diagnostika strojů a výrobních zařízení „DIAGO 2012". Ostrava : VŠB - Technical University of Ostrava, 2012. pp. 376-380. ISSN 1210-311X.

\section{Contact address:}

Jiří Votava, Mendel University in Brno, Faculty of Agronomy, Department of Technology and Automobile Transport, Zemědělská 1, 61300 Brno, Czech Republic, e-mail: jiri. votava@mendelu.cz 